\title{
DE GESCHIEDENIS VAN DEN KONINKLIJKEN SLAAF
}

DOOR

\author{
APHRA BEHN
}

(Vervolg)

De heer, die hem gekocht had, was een jonge man uit Cornwallis, Trefry genaamd; een man van groot verstand en degelijke kennis, die in dat district geplaatst was door den LordGouverneur, om al diens zaken te leiden. Over de laatste woorden van Oroonoko tot den kapitein nadenkend, en de rijkdom van zijn kleeding ziende, was hij nauwelijks in de boot gekomen, of hij vestigde zijn blikken op hem ; en daar hij op zijn gelaat, in zijn gestalte en voorkomen iets zoo bijzonders, voornaamheid van blik en hoogheid van houding aantrof, en bemerkend dat hij Engelsch sprak, voelde hij zich er zeer toe aangetrokken om navraag te doen naar zijn rang en lotgevallen; tenaanzien waarvan Trefry, hoewel Oroonoko die, door enkel toe te geven, dat hij boven den rang van gewone slaven stond, trachtte te verbergen, spoedig uitvond, dat hij iets nog grooters was, dan hij erkende; en vanaf dat oogenblik een zoo groote achting voor hem begon op te vatten, dat hij hem daarna voor altijd liefhad als zijn liefste broeder, en hem al de voorkomendheden betoonde, die een zoo voornaam man toekwamen.

Trefry was een uitstekend wiskundige en talenkenner, kon Fransch en Spaansch spreken; en gedurende de drie dagen, dat zij in de boot bleven (want zoo lang duurde de tocht van het schip naar de plantage) onderhield hij Oroonoko zoo aangenaam door zijn optreden en zijn gesprekken, dat hij niet minder ingenomen was met Trefry, dan deze met den Prins; en hij overwoog dat hij tenminste hierin gelukkig was, dat hij, nu hij eenmaal, zoolang hij er tenminste bij berustte zulks te blijven, slaaf was, een man van zoo uitnemend verstand en optreden als meester had. Zoodat hij, vóór zij hun reis de rivier op beeindigd hadden, geen bezwaar meer had Trefry al zijn lotgevallen mede te deelen, en het grootste gedeelte van wat ik hier verteld 
heb, en zich geheel en al aan zijn nieuwen vriend toevertrouwde, van wien hij zag, dat hij al het onrecht dat hem was aangedaan, betreurde en onder den invloed was van al zijn groote daden; die met zulk een bescheidenheid en fijngevoeligheid voorgedragen werden, dat zij hem heelemaal overwonnen, en hem aan zijn belangen onderworpen maakten. En hij beloofde hem, op zijn woord en eer, dat hij de middelen zou vinden, om hem weer naar zijn eigen land terug te voeren; hem verzekerend, dat hij een volmaakte afschuw had van een zoo schandelijke handelwijze ; en dat hij liever gestorven zou zijn, dan zich aan zulk een trouwbreuk te hebben schuldig gemaakt. Hij bemerkte, dat het den Prins ten zeerste bezorgd maakte te weten, wat van zijn vrienden geworden was, en hoe zij hun slavernij opnamen; en Trefry beloofde dat hij zorg zou dragen voor een onderzoek naar hun omstandigheden, en dat hij er een verslag van krijgen zou.

Ofschoon Oroonoko, zooals hij later zeide, weinig reden had om aan de woorden van een Backearary geloof te slaan; toch, hij wist niet waarom, zag hij een soort oprechtheid, en ontzaginboezemende waarachtigheid in het gelaat van Trefry; hij zag fatsoen in zijn oogen, en hij bemerkte, dat hij verstandig en wijs genoeg was om te begrijpen wat eer is : want het was een zijner leerstellingen : een man van geest kon geen bedrieger of een schurk zijn.

Tijdens hun tocht de rivier op, legden zij bij verschillende huizen aan om te eten, en telkens wanneer zij landden, stroomden talrijke menschen toe om hem te zien; niet dat hun oogen niet dagelijks aan het gezicht van slaven gewend waren, maar de roep over Oroonoko was hem vooruitgegaan, en iedereen was vol bewondering voor zijn schoonheid. Bovendien had hij een rijk gewaad aan, zoo verschlllend van de rest, waarin hij gevangen genomen was, en waar de kapitein hem niet van had kunnen ontrooven, omdat hij genoodzaakt was bij verrassing de hand op zijn persoon te leggen op het oogenblik, dat hij hem verkocht. Toen hij merkte dat zijn gewaad, zooals hij dacht, de aanleiding was, om des te meer te worden angestaard, vroeg hij Trefry hem iets te geven, dat meer voor een slaaf geschikt was, hetgeen deze deed, en hij legde zijn kleederen af: desniettegenstaande, scheen hij door alles heen, en zijn Osnabrugsch (een soort bruine Hollandsche kleedij die hij aan had) kon de bekoorlijkheid van 
zijn uiterlijk en voorkomen niet verbergen; en hij had niet minder bewonderaars, dan toen hij zijn schitterend gewaad droeg. De Koninklijke Jongeling verscheen in spijt van den slaaf, en de menschen konden niet helpen, dat zij hem, zonder het van plan te zijn, op een andere manier behandelden. Zoodra zij hem naderden, eerden en achtten zij hem; onwillekeurig dwongen zijn oogen ontzag af, en aan elk gemoed boezemde zijn gedrag dat in. Zoo dat men over niets anders sprak, dan over dezen jongen en ridderlijken slaaf, zelfs zij, die nog niet wisten dat hij een prins was.

Ik moet $\mathrm{u}$ vertellen, dat de Christenen nimmer slaven koopen of zij geven hun den een of anderen naam van hen zelf, daar hun eigen namen waarschijnlijk zeer barbaarsch zijn, en moeilijk uit te spreken; zoodat mijnheer Trefry Oroonoko dien van Caesar gaf; welke naam in dat land even lang zal leven, als die (nauwelijks méér) roemrijke van den grooten Romein; want zonneklaar is het dat hij niets van den persoonlijken moed van dien Caesar miste, en dingen verrichtte even gedenkwaardig, waren zij uitgevoerd in een deel der wereld dat vol was met menschen en geschiedschrijvers, die hem hadden kunnen geven, wat hem toekwam. Maar zijn ongeluk was, dat hij in een onbekende wereld viel, die alleen een vrouwelijke pen opleverde om zijn roem te verheerlijken; ofschoon ik niet twijfel, of deze ware ook door pogingen van anderen blijven leven, als niet de Hollanders, die onmiddellijk na zijn tijd dat land veroverden, al diegenen gedood, verbannen en verstrooid hadden, die in staat waren de wereld het leven van dezen grooten man veel beter te vertellen, dan ik het gedaan heb. En de heer Trefry, die daar toe het plan had, stierf voor hij het begonnen had, en beklaagde zich zelf, dat hij het niet bij tijds ondernomen had.

Voor het vervolg moet ik Oroonoko dus Caesar noemen, daar hij in onze westelijke wereld alleen bij dien naam bekend was, en bij dien naam werd hij aan den oever bij Parham-Huis, waar hij bestemd was als slaaf te dienen, ontvangen. Maar als de koning zelf (God zegene hem) aan wal gekomen ware, zou er bij de geheele plantage, en die, welke in de nabuurschap lagen, geen grooter verwachting geweest kunnen zijn, dan in dien tijd op de onze : en hij werd meer als een gouverneur dan als een slaaf ontvangen: desniettegenstaande, zooals de gewoonte was, 


\section{2}

wezen zij hem zijn stukje land, zijn huis en zijn bezigheid op de plantage toe. Maar daar het meer voor den vorm was, dan uit eenige bedoeling, om hem aan het werk te zetten, had hij van een slaaf alleen den naam te verduren, en vertoefde eenige dagen in het huis, al de bezoeken, die bij hem werden afgelegd, ontvangend, zonder zich naar dat deel der plantage waar de negers waren te begeven.

Ten slotte was hij genoodzaakt zijn land, zijn huis, en het hem toegewezen werk te gaan opnemen. Maar nauwelijks was hij bij de huizen der slaven, die wel een kleine stad op zich zelf lijken, anngekomen, of de negers die hun werk allen hadden laten liggen, kwamen allemaal naar buiten om hem te aanschouwen, en ontdekten dat hij die Prins was die, op verschillende tijden, het meerendeel hunner naar deze streken verkocht had, en uit een soort vereering die zij voor groote mannen hebben, vooral als $z$ ij hen kennen, en vol van de verwondering en het ontzag die zij bij zijn aanblik gevoelden, wierpen zij zich allen aan zijn voeten, in hun taal uitroepend: „Leef, o Koning! Leef lang, o Koning!" en betoonden hem, onder het kussen zijner voeten, zelfs godsdienstige eer.

Verscheiden Engelsche heeren waren bij hem; en wat mijnheer Trefry hun verteld had, werd hier bevestigd; waarvan hij zelf te voren geen andere getuige gehad had dan Caesar zelf. Maar hij was oneindig verheugd om zijn hoogheid door de vereering van alle slaven bevestigd te vinden.

Caesar, aangedaan door hun overmaat van vreugde en eerbetoon, verzocht hen op te staan, en hem als hun medeslaaf in hun midden te ontvangen, hen verzekerend, dat hij niets meer was. Waarop zij eenstemmig een allerverschrikkelijkst en afschuwelijkst rouw- en leedbeklag aanhieven, dat hij en de Engelschen slechts met veel moeite tot bedaren konden brengen: maar ten slotte slaagden zij er in, en zij brachten al hun barbaarsche muziek in gereedheid, en elk hunner doodde en bereidde iets van zijn eigen voorraad (want elke familie heeft haar eigen land, waarop zij, in hun vrijen tijd, alle mogelijke eetbare dingen kweeken) en het te zamen voegend, maakten zij een schitterend avondmaal, hun Groote Kapitein, hun Prins uitnoodigend, het met zijn tegenwoordigheid te vereeren; hetgeen hij deed, en verscheidene Engelschen met hem, waarbij zij hem allen van dienst waren, sommigen door te spelen, anderen door 
den geheelen tijd voor hem te dansen, naar gelang van de zeden hunner verschillende naties, en door met onvermoeide ijver te trachten hem te vermaken en behagelijk te stemmen.

Terwijl zij aan den maaltijd zaten, vertelde de heer Trefry aan Caesar, dat de meesten dezer jonge slaven heelemaal in de war waren van liefde voor een mooie slavin, die zij sinds omstreeks zes maanden op hun land gezien hadden; de Prins, die nooit het woord liefde hoorde zonder een zucht, noch er ooit melding van hoorde maken zonder de aandrang om dieper door te dringen in dat onderwerp, dat hem van alle gesprekken het aangenaamst was, vroeg, hoe zij zoo ongelukkig kwamen, geheel en al in de war te zijn om een mooie slavin? Trefry die verliefd van aard was en zoo goed als ieder ander graag over liefde sprak, ging verder met zijn verhaal en vertelde, dat zij de bekoorlijkste zwarte die ooit op hun plantage gezien'was, hadden, omstreeks I5 of I6 jaar oud, naar hij giste ; dat wat hem betreft hij sinds haar komst niets gedaan had dan om haar zuchten ; en dat al de blanke schoonheden, die hij gezien had, hem nooit zoo volkomen bekoord hadden als dit mooie schepsel gedaan had; en dat geen man, van welke natie ook, haar ooit aanschouwd had zonder op haar verliefd te worden; en dat al de slaven bij voortduring aan haar voeten lagen: en de geheele straat weerklonk van de roep van Clemene, want zco (zeide hij) hebben wij haar gedoopt : maar zij wijst ons allen af met een zoo edele verachting dat het een wonder is te zien, dat zij die zoo eeuwige -verlangens inboezemt, zelf niets dan ijs en onverschilligheid is. $Z_{\mathrm{ij}}$ heeft het sieraad van de bekoorlijkste ingetogenheid die ooit de jeugd haar schoonheid gaf; de zachtste zuchtster, zoo, dat men, als zij tot liefde in staat was, zou zweren dat zij kwijnde terwille van een afwezig man; en zoo teruggetrokken, als of zij vreesde zelfs door den God Des Daags ontvoerd te worden, of dat de wind kussen zou stelen van haar teederen mond. Haar arbeidstaak, iederen dag maakt de een of andere zuchtende minnaar er een smeekbede van, om die voor haar te mogen verrichten ; hetgeen zij blozend aanvaardt, en met tegenzin, uit vrees dat hij haar voor belooning een blik zal vragen, waarop hij de vrijpostigheid niet durft te hebben om te hopen, met zoo groot ontzag treft zij de harten van haar bewonderaars. „Het verbaast mij niet," antwoordde de Prins, „dat Clemene slaven weigert, schoon als zij, naar uw zeggen, immers is ; maar wel verbaast 
het mij hoe zij ontkomt aan hen, die zich met haar kunnen onderhouden als gij, of waarom, daar zij uw slaaf is, gij haar niet tot overgave dwingt ?” „Ik beken, zeide Trefry, dat, toen ik haar tegen haar wil zoo lang over mijn liefde onderhouden had, dat ik door mijn hartstocht vervoerd was tot boven het betamelijke, ik klaar geweest ben om van die voordeelen van kracht en sterkte gebruik te maken, die de natuur mij gegeven heeft. Maar o, zij ontwapent mij door die ingetogenheid en dit weenen, zoo teeder en aandoenlijk, dat ik mij van zelf terug trek, en mijn ster dank, dat zij de overmacht over mij gehouden heeft." Het gezelschap lachte over zijne hoffelijkheid tegen eene slavin, maar Caesar kon slechts de adel van zijn hartstocht en karakter toejuichen, daar die slavin van adel kon zijn, of, wat beter was, ware begrippen van eer en deugd in zich kon hebben. Zoo brachten zij die nacht door, na van de slaven alle mogelijke eerbewijs en gehoorzaamheid ondervonden te hebben.

Den volgenden dag vroeg Trefry Caesar om, als de hitte was afgenomen, te gaan wandelen en bracht hem opzettelijk bij de hut der mooie slavin; en vertelde hem, dat zij, over wie zij de vorige avond gesproken hadden, daar teruggetrokken leefde : „Maar, zeide hij, ik zou niet wenschen dat gij in haar nabijheid komt ; want ik ben zeker, dat gij, zoodra gij haar aanschouwt, verliefd zult worden". Caesar verzekerde hem, dat hij ontoegankelijk was voor de bekoringen dier sexe, en dat hij, als hij zich ook maar verbeeldde, dat zijn hart zoo trouweloos kon zijn om na Imoinda weder lief te hebben, geloofde, het uit zijn boezem te zullen scheuren. Nauwelijks hadden zij dit gezegd, of een kleine ruige hond, die Clemene ten geschenke gekregen had, en waar zij veel pleizier in had, liep naar buiten; en zij, niet wetende, dat daar iemand was, liep naar buiten om hem binnen te halen. Maar Trefry pakte haar bij haar hand, en riep: "Clemene, hoe je ook een minnaar ontvlucht, toch moest je dezen vreemdeling eenig respect betoonen", op Caesar wijzend. Maar zij, alsof zij besloten had haar oogen nimmer meer naar het gelaat van een man op te slaan, neigde hen des te meer naar den bodem, toen hij sprak, en gaf den Prins gelegenheid te beter naar haar te kijken. Er was geen lang staren noodig, noch een lange beschouwing, om te weten te komen, wie dit schoone schepsel was; hij zag spoedig aan alles van haar Imoinda ; in een oogenblik zag hij haar gelaat, haar gestalte, haar 
houding, haar ingetogenheid, en dat alles riep zijn ziel met blijdschap naar zijn oogen te voorschijn, en liet zijn lichaam bijna ontdaan van leven : het stond bewegingloos, en wist voor een oogenblik niet, dat het leefde; en ik geloof, dat hij nooit tot zich zelf gekomen ware, zoo overweldigd was hij door overmaat van vreugde, als hij niet deze ontspanning gevonden had, dat hij Imoinda als dood in de armen van Trefry zag vallen. Dit deed hem tot zich zelf komen, en hij liep haar te hulp, en vatte haar in zijn armen, waar zij langzamerhand tot zich zelf kwam; en het is onnoodig te zeggen, met welke vervoeringen, welke verrukkingen van vreugde zij beiden elkander een tijdlang zonder spreken aanschouwden; dan elkander in de armen drukten; dan opnieuw staarden, als twijfelden zij nog, of zij de zaligheid, die zij vast gegrepen hadden, bezaten : maar toen zij hun spraak terug hadden, men kan zich niet voorstellen, hoe teedere dingen zij elkander toen toevoegden, vol verwondering, welk vreemd spel van het noodlot hen weer tezaam gebracht had. Zij vertelden elkaar spoedig hun lotgevallen, en betreurden gelijkertijd hun lot; maar te zelfder tijd betuigden zij wederkeerig, dat zelfs boeien en slavernij zacht en gemakkelijk waren, en met vreugde en blijdschap gedragen zouden worden, waar zij zoo gelukkig konden zijn elkander te bezitten, en in staat te zijn, hun geloften na te komen. Caesar zwoer dat hij de heerschappij der wereld verachtte, zoolang hij zijn Imoinda aanschouwen kon, en zij keek neer op grootheid en praal, die ijdelheden van haar kunne, wanneer zij naar Oroonoko zien kon. Hij aanbad zelfs de hut, waar zij verblijf hield, en zeide, dat dat kleine stukje wereld hem meer geluk zou geven, dan het gansche heelal doen kon; en zij getuigde, dat het, verlucht door de aanwezigheid van Oroonoko, een paleis was.

Trefry was bovenmate verheugd over dit nieuws, en hoorde, dat deze Clemene de schoone geliefde was, over wie Caesar hem te voren gesproken had; en hij was niet weinig voldaan, dat de hemel den Prins zoo vriendelijk gezind was, om zijn ongeluk door een zoo gelukkig toeval te verzoeten; en de geliefden aan hen zelf overlatend, was hij vol ongeduld om naar ParhamHuis (dat op de zelfde plantage lag) te komen, om mij verslag af te leggen over wat gebeurd was. Ik was even ongeduldig om deze geliefden een bezoek te maken, daar ik met Caesar al vriendschap gesloten en uit zijn eigen mond vernomen had, 
wat ik verteld heb; hetgeen bevestigd werd door zijn Franschman, die aan land gezet was om zijn fortuin te zoeken, en van wien zij geen slaaf konden maken, omdat hij een Christen was ; en hij kwam dagelijks naar Parham-heuvel om zijn Prinselijken leerling te zien en zijn respect te betuigen. Zoo dat ik mij, vol bemoeienis en belangstelling voor alles wat op?Caesar, dien ik verzekerd had dat hij zijn vrijheid herkrijgen zou zoodra de Gouverneur aankwam, betrekking had, dadelijk naar de plaats haastte, waar deze geliefden waren, en oneindig blij was te bevinden, dat deze mooie jonge slavin (die alreeds al onze achting om haar ingetogenheid en buitengewone bevalligheid gewonnen had) dezelfde was, over wie ik Caesar zoo veel had hooren spreken. Men kan zich voorstellen, dat wij toen een drievoudige achting voor haar hadden; en ofschoon wij haar, door dat zij over haar geheele lichaam met mooie bloemen en vogels getatoueerd was, ook vroeger al voor iemand van stand hielden, toch konden wij haar, toen wij wisten, dat Clemene Imoinda was, niet genoeg bewonderen.

Ik heb vergeten $\mathrm{u}$ te vertellen, dat zij die in dat land in den adelstand geboren zijn, zoo fijn over de voorzijde van de romp hunner lichamen gekerfd en opgehoogd worden, dat het er uit ziet of het lakwerk is, daar de figuren als reliefkant om de zoomen der bloemen worden opgehoogd. Bij sommigen, zooals Caesar, wordt alleen een kleine bloem, of een vogel, op het vlak der slapen ingekerfd, en zij, die zoo over het geheele lichaam getatoueerd zijn, gelijken onze oude Picten, die in de kronieken afgebeeld staan, maar dit kerfwerk is fijner.

Sinds dien gelukkigen dag nam Caesar Clemene tot vrouw, tot de algemeene vreugde van al het volk; en er was bij de voltrekking van het huwelijk zooveel praal, als de streek verschaffen kon : en binnen zeer korten tijd daarna werd zij zwanger van een kind, dat Caesar in de wetenschap dat hij de laatste van zijn geslacht was, er nu toe bracht haar zelfs te aanbidden. Deze nieuwe gebeurtenis maakte hem ongeduldig om zijn vrijheid te herkrijgen, en iederen dag onderhandelde hij met Trefry over zijn en Clemene's vrijheid, en bood hem hetzij goud, hetzij een groote hoeveelheid slaven aan, welke betaling zou plaats hebben, voor zij hem gaan lieten, mits hij eenige zekerheid kon hebben, dat hij zou heengaan, wanneer zijn losgeld betaald was.

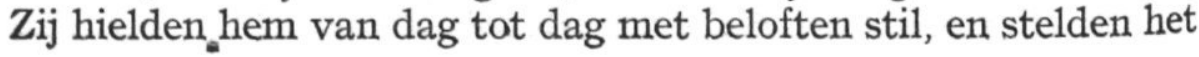


antwoord uit, tot de komst van den heer Gouverneur; zoodat hij hen van valschheid begon te verdenken, en dat zij hem aan het lijntje wilden houden tot den tijd van de bevalling zijner vrouw, en ook van het kind een slaaf maken ; want al de kinderen behooren aan hen, aan wie de ouders behooren. Deze gedachte maakte hem zeer ongerust, en zijn neerslachtigheid boezemde hun argwaan in, zoodat ik door sommige lieden, die bang waren voor een oproer (hetwelk somtijds zeer noodlottig is in die koloniën, waar de slaven zoo overvloedig zijn, dat zij de blanken in grooten getale overtreffen) genoopt werd mij met Caesar te onderhouden, en hem al de voldoening te geven, waartoe ik maar eenigszins in staat was. $Z$ ij wisten, dat hij en Clemene nauwelijks een uur per dag mijn verblijf verlieten; dat zij met mij aten, en dat ik hen, met alles, waartoe ik in staat was, verplichtte. Ik gaf hen afleiding door hun de levens der Romeinen en groote mannen te vertellen, die hem behagen in mijn gezelschap deden stellen ; en haar, door haar al de aardige handwerken te leeren, die ik meester was, en door haar verhalen van nonnen te vertellen en te trachten, haar tot de kennis van den waren God te brengen. Maar van alle onderwerpen van gesprek, hield Caesar dáárvan het minst, en hij kon nooit verzoend raken met onze begrippen over de Drieëenheid, waar hij altijd een grap van maakte ; het was een raadsel, van hetwelk hij zeide dat het hem gek zou maken, als hij zou trachtten het te begrijpen, en men kon $\mathrm{h} \in \mathrm{m}$ niet aan het verstand brengen, wat geloof is. Niettemin, deze gesprekken faalden er niet zoo in, hem afleiding te verschaffen, dat hij het gezelschap van ons vrouwen niet verre verkoos boven de mannen, want hij kon niet drinken, en wie dat niet kan doen, gaat in dat land voor een slechte gezel door. Zoo dat wij, door hem er toe te brengen veel van ons te houden, in den omgang met hem volkomen vrijheid van spreken hadden, ik vooral, die hij zijn "Groote Meesteres” noemde ; en inderdaad legde mijn woord een groot gewicht bij hem in de schaal. Om deze redenen had ik de gelegenheid bij hem op te merken, dat hij in den laatsten tijd niet heelemaal opgewekt was, zooals hij placht te zijn; dat hij meer teruggetrokken en in gedachten verzonken was; en zeide hem, dat ik het niet goed van hem vond, om argwaan te koesteren, dat wij ons woord met hem zouden breken, en hem en Clemene niet vergunnen zouden om naar zijn eigen koninkrijk terug te keeren, hetgeen niet zulk een 
groote afstand was, maar wanneer hij eenmaal op reis was, zou hij daar spoedig ankomen. Hij gaf mij een paar antwoorden, die bewezen dat er twijfel in hem was, hetgeen mij hem vragen deed, welk voordeel het zou opleveren om te twijfelen ? Het zou ons slechts vrees voor hem inboezemen en ons misschien dwingen hem zoo te behandelen, als ik zeer ongaarne zien zou; dat wil zeggen, het zou zijn opsluiting kunnen veroorzaken. Misschien was dit van mij geen gelukkige uitlating, want ik bemerkte, dat dit woord, dat ik vergeefs weer trachtte te verzachten, hem onaangenaam trof : evenwel, hij verzekerde mij dat hij, welk besluit hij ook zou nemen, niets tegen de blanken doen zou; en wat mij zelf betreft, en hen, die op de plantage waar hij vertoefde, waren, hij zou liever zijn eeuwige vrijheid, en het leven zelf, verbeuren, dan op die plaats zijn hand op te heffen tegen zijn grootsten vijand. Hij verzocht mij op dit stuk geen vrees te koesteren, want hij kon niets doen, wat de eer hem niet voorschreef . maar hij beschuldigde zichzelf dat hij zoo lang de slavernij verdragen had ; toch weet hij die zwakheid enkel aan de liefde, die in staat was hem zelfs zijn roem te doen verwaarloozen; waarcm hij zich zelf nu ieder oogenblik van den dag verwijten toevoegde. Hij sprak nog veel meer in dezen geest, met een houding, welke ongeduldig genoeg was om mij te doen beseffen, dat hij niet lang meer in slavernij verkeeren zou, en ofschoon hij alleen den naam van slaaf te dulden had, en niets van het wee en het gezwoeg van een slaaf op hem rustte, toch was dat voldoende om hem onrustig te maken; en hij, die altijd in beweging, en onder de wapenen placht te zijn, had te lang in ledigheid geleefd. Hij had een geest een en al onstuimigheid en vurigheid, en die konden niet tot loome rust getemd worden; en ofschoon hij alle pogingen aanwendde om zich te oefenen in zulke bezigheden en vermaken, als dat land opleverde, als hardloopen, worstelen, stokwerpen, jagen en visschen, achtervolgen en dooden van reusachtige tijgers, die dit vasteland in overvloed opleverde; en wonderbaarlijke slangen, zooals Alexander, naar verhaald wordt, er tegenkwam aan de Amazonenrivier, en welke te overmeesteren Caesar veel vreugde verschafte; toch waren dit geen bezigheden belangrijk genoeg voor zijn groote ziel die steeds naar meer roemruchte daden hunkerde.

Voor ik dien dag van hem scheidde, verkreeg ik, met veel moeite, een belofte van hem, dat hij nog een weinig langer ge- 
duld zou oefenen, en de komst van den heer Gouverneur afwachten, die iederen dag aan onze oevers tegemoet gezien werd. Hij verzekerde mij, dat hij dit doen zou en stelde er prijs op dat ik wist, dat deze belofte uitsluitend werd afgelegd om mij, in wie hij het volst vertrouwen stelde, genoegen te doen.

Hierna dacht noch ik, noch de overheid van de streek, die bang voor hem was, het passend hem dikwijls uit het gezicht te laten, maar eenparig werd besloten hem netjes te behandelen, hem de verplichting op te leggen om binnen een bepaalden omtrek te blijven, en hem zoo zelden mogelijk te vergunnen, naar de plantages der negers te gaan, of, wanneer hij dat deed, door menschen vergezeld te worden, die, naar den schijn, meer bedienden dan spionnen zouden zijn. Voor eenigen tijd nam men deze voorzorg, en Caesar beschouwde het als een teeken van buitengewoon respect, en was blijde, dat zijn ontevredenheid hen genoopt had hem met meer voorkomendheid te behandelen; hij ontving een nieuwe verzekering van den opzichter, welke versterkt werd door de meening van al de heeren van het land, die hem het hof maakten. Het is misschien niet onaardig te vertellen met welke afleidingen wij hem, of liever hij ons geduren dezen tijd, waarin wij vaker in zijn gezelschap waren dan te voren het geval geweest was, bezighield.

Het stond vast dat mijn verblijf in dat land maar kort zou zijn, omdat mijn vader op zee stierf en nooit in het bezit van de eereplaats geraakte, die men voor hem bestemd had, (welke Luitenant-Generaal van zes en dertig eilanden benevens het vasteland van Suriname was) noch van de voordeelen, welke hij gehoopt had daardoor te zullen oogsten : zoodat wij, ofschoon wij genoodzaakt waren onze reis te vervolgen, niet van plan waren op die plaats te blijven. Hoewel ik, met een enkel woord, nog het volgende over haar wensch te zeggen : dat wijlen Zijne Majesteit, zaliger gedachtenis, had hij slechts gezien en geweten welk een uitgestrekte en bekoorlijke wereld hij in dat vasteland bezat, er nimmer zoo gemakkelijk ten behoeve der Hollanders van gescheiden zou zijn. Het is een vasteland welks geweldige uitgestrektheid nog nooit geheel opgenomen is, en misschien meer voortreffelijke aarde bevat dan de heele rest van de wereld, want, naar men zegt, reikt het naar de eene zijde van oost tot west zelfs tot aan China, en naar een andere zijde tot aan Peru. Het levert alle mogelijke dingen, zoowel ter verfraaiïng 
als voor nuttigheid op ; het is daar eeuwige lente, altijd zoo als bij ons alleen April, Mei en Juni zijn; het is onafgebroken lommerrijk, daar de boomen te gelijk alle stadiën van bladeren en vruchten, van bloeiende knoppen tot rijp herfstoogst dragen; boschjes oranjes, limoen- en citroenboomen, vijgeboomen, nootmuskaatboomen, en edele reukkruiden, die voortdurend geur verspreiden, al de boomen als groote ruikers, met bloemen van verschillende soorten versierd; sommige zijn heelemaal wit, of purper, andere scharlaken of blauw of geel, tezelfder tijd rijpe en donzige pas-gezette vruchten dragend, of iederen dag nieuwe voortbrengend. Het hout zelf van al deze boomen heeft een speciale waarde, boven gewoon timmerhout; want als men ze zaagt, zijn zij van verschillende kleuren, prachtig om te zien, en brengen een flinken prijs op, voor inlegwerk bovendien. Behalve dat, leveren zij uitnemende balsems en gommen; zoodat wij onze kaarsen van zulk een geurige stof maken, dat zij niet alleen voldoende licht geven, maar als zij branden, hun geuren overal in het rond verspreiden. Cederhout is de gewone brandstof, en alle huizen worden er mee gebouwd. Zelfs het vleesch dat wij eten, als het van eigen teelt, ik bedoel uit het land is maakt de heele kamer geurig ; in het bijzonder een klein beest, dat Armadillo heet, een ding dat ik bij niets zoo goed kan vergelijken als bij een rhinoceros; het zit heelemaal in een witte rusting, zoo samengevoegd dat het zich er even goed in beweegt alsof het niets aan had. Dit beest heeft ongeveer den omvang van een varken van zes weken. Maar er kwam geen eind aan, wanneer ik verslag wou afleggen van al de verschillende wonderbaarlijke en vreemde dingen, die dat land oplevert, en waarnaar wij buitengewoon gaarne op zoek gaan; hoewel die avonturen dikwijls noodlottig, en ten minste gevaarlijk zijn. Maar terwijl wij Caesar bij deze ondernemingen in ons gezelschap hadden, vreesden wij geen ongeval en ondervonden er ook geen.

Zoodra ik in het land was, bood men mij het beste huis, Sint Jans Heuvel genaamd aan. Het stond op een groote rots van wit marmer, aan welks voet ver in de diepte de rivier stroomde, en waar langs men aan dien kant niet kon afdalen; de kleine golven, steeds tegen de voet van den rots klotsend en spoelend, makte het zachtste gemurmel en gekabbel der wereld; en de overzijdsche oever was met zulke enorme hoeveelheden ver- 
schillende, eewig bloeiende, elken dag en ieder uur versche bloemen getooid, met een scherm daarachter van statige, op duizenderlei wijs gevormde en getinte boomen, dat het uitzicht het verrukkelijkste was, hetwelk de fantaisie kan voortbrengen. Aan den zoom van deze witte rots, naar de rivier toe, was een wandelpad, of boschje, van oranje-en limoenboomen, omstreeks de halve lengte van de Mall hier, welks bloemrijke en vruchtdragende takken aandetopelkander ontmoetten, en de zon, wier stralen daar steeds vurig zijn verhinderden met een enkele straal in het boschje door te dringen; en de koele lucht die van de rivier kwam, maakte het niet alleen geschikt om er op al de heetste uren van den dag menschen in te ontvangen, maar verfrischte ook de teere bloesems, en maakte het altijd aangenaam en bakoorlijk; en voorwaar, de heele wereld kan niet zulk een heerlijke plek aanwijzen als dit boschje was : niet al de tuinen van het roemruchte Italië kunnen een lommer voortbrengen, dat met dit kan wedijveren, hetwelk natuur en kunst tezamen zoo bovenmate schoon maakten; en het is een wonder om te zien hoe zulke reusachtige boomen, zoo groot als Engelsche eiken, op zulk een harde rots en in zoo weinig aarde als die rots bedekte, wortel konden schieten. Doch alle dingen zijn daar van nature zoo zeldzaam, heerlijk en wonderlijk. Maar nu onze uitspanningen.

Soms plachten wij jonge tijgers te verrassen en in hun hol op te zoeken, er acht op gevend wanneer de oude voor voedsel op prooi uitgingen : en dikwijls hebben wij in groot gevaar verkeerd, en snel ons leven door de vlucht moeten redden, als wij door de tijgermoeders verrast werden. Maar eenmaal, boven alle andere keeren, gingen wij met dit doel uit, en Caesar was bij ons en nauwelijks had hij een jonge tijger uit zijn nest gestolen, of wij kwamen de moeder tegen, welke met het achtereind van een koe, dat zij met haar machtige klawwen had afgescheurd, in haar muil naar haar hol ging. Wij waren enkel met vier vrouwen, Caesar, en een Engelschen heer, de broeder van Harry Martin, den grooten Cromwellist; wij zagen dat er geen ontsnappen was aan dit razende en roofgierige dier. Evenwel, wij vrouwen vluchtten zoo snel wij konden weg; maar onze voeten zouden onze levens niet gered hebben, als niet Caesar, toen hij zag dat de tijger haar prooi in de steek liet, om hem met des te meer spoed te bereiken, haar jong had neergelegd en, mijnheer Martins sabel ter hand nemend dezen gevraagd had om ò hem bij 
te staan, òf de dames te volgen. Hij gehoorzaamde hem, en Caesar kwam tot een ontmoeting met dit monsterachtige dier, dat kolossale afmetingen en reusachtige ledematen had en met open kaken op hem afkwam ; en zijn ontzagwekkende, strenge oogen recht op die van het dier richtend, en een zeer vaste en doelzekere verdedigende houding aannemende, stootte hij zijn zwaard dwars door het dier, tot diep in zijn hart en tot aan het gevest van zijn zwaard. Het stervend beest strekte haar klauwen uit maar op het punt om zijn dij vast te grijpen, in dat zelfde oogenblik door den dood verrast, deed zij hem geen ander kwaad dan dat zij hem, door haar lange nagels heel diep in zijn vleesch te drukken, een lichte wond toebracht, doch het vleesch kon zij niet vastgrijpen, om er een stuk af te scheuren. Toen hij dat gedaan had, gaf hij ons eens signaal om terug te keeren; hetgeen wij, na eenige zekerheid van zijn overwinning verkregen te hebben, ook deden en wij troffen hem aan, terwij1 hij zijn zwaard trok uit de borst van de tijger, die in haar bloed op den grond lag. Hij nam het jong op, en met een onbekommerdheid die niets van vreugde of blijdschap van een overwinning had, kwam hij de welp aan mijn voeten leggen. Wij waren allen titermate verwonderd over zijn moed, en over den omvang van het dier, dat omtrent de hoogte van een vaars, maar geweldig groote en sterke leden had.

Een andere keer, toen hij in de bosschen was, doodde hij een tijger, die lang die streek onveilig gemaakt had, en een menigte schapen en ossen en andere dieren, bestemd voor het onderhoud van hen, aan wie zij toebehoorden, geroofd had. Een massa menschen viel dit dier aan, sommigen bewerend dat zij het verschillende kogels verscheiden malen dwars door het lichaam geschoten hadden; en anderen zwerend, dat zij zelfs zijn hart doorboord hadden; en zij geloofden dat het meer een duivel dan een sterfelijk ding was. Caesar had vaak gezegd dat hij zin had dat monster op te zoeken, en sprak met verscheiden heeren, die het hadden aangevallen; waarbij de een uitriep; ,ik raakte hem met zóóveel vergiftige pijlen," een ander met zijn geweer in dit, nog een ander in dat deel; zoodat hij, al de plaatsen opmerkend, waar men hem geraakt had, zich voorstelde dat hij hem overmeesteren zou door hem een andere soort wonde toe te brengen dan een der anderen tot nu toe gedaan had; en op een dag zeide hij (aan tafel) ,Wat voor zegeteekenen en kransen, 
dames, wilt gij voor mij maken, als ik $\mathrm{u}$ het hart van dit roofgierig dier thuis breng, dat al uw lammeren en biggen verslindt?" Wij beloofden hem allen, dat hij uit onze handen zijn loon ontvangen zou. Aldus na een boog genomen te hebben, die hij uit een massa had uitgezocht, verwijderde hij zich met twee mannen het woud in, waar hij meende dat de verslinder vertoefde. $\mathrm{Zij}$ waren er nog niet erg ver in doorgedrongen, toen zij zijn stem hoorden, brommende en knorrende, als of hij pleizier had in iets waar hij mee bezig was. Toen zij in het gezicht kwamen, vonden zij hem snuffelend in de buik van een pas geroofd schaap, dat hij opengescheurd had; en ziende, dat er menschen in de buurt kwamen, pakte hij zijn prooi stevig met zijn roofklauwen vast, en wierp een uiterst wilde, woedende blik op Caesar, zonder dat hij klaarblijkelijk op hem toe wou komen, uit vrees dat hij te zelfder tijd verliezen zou wat hij in zijn bezit had. Zoo dat Caesar een tijd lang kon stil staan, en enkel maar op hem mikte en een goede gelegenheid afwachtte om hem te raken waar hij van plan was. Het duurde eenigen tijd voor hij dat volbrengen kon; en hem te wonden en niet te dooden, zou hem des te woedender gemaakt, en hem in gevaar gebracht hebben. Hij had een pijlkoker aan zijn zijde, zoodat hij, als er een miste, een ander in de plaats kon nemen. Tenslotte gaf hij hem, door zich een klein eindje terug te trekken de gelegenheid om te eten, want hij bemerkte dat het dier hongerig was, en het schaap begon te verslinden, zoodra het zag dat hij zich terugtrok, begeeriger naar zijn prooi dan naar het verrichten van nieuwe wandaden; maar hij, naar een kant om hem heensluipend, en zijn lichaam achter zekere gewassen die hoog en dicht groeiden, verbergend, mikte zoo goed op hem dat hij hem zooals zijn plan was, juist in het oog raakte, en de pij1 was met zooveel kracht, en met een zoo vaste hand afgeschoten, dat hij in zijn hersens bleef steken, en hem krampachtige sprongen deed maken en voor een paar minuten gek worden, maar met behulp van een tweede pijl viel hij dood op zijn prooi. Caesar sneed hem open met een mes, om te zien waar die wonden waren, waarover men hem bericht had, en waarom hij er niet aan gestorven was. Maar nu zal ik iets vertellen, dat misschien onder de menschen geen geloof zal vinden ; omdat het een gewone meening van ons is, dat niets een wond in het hart kan krijgen en toch blijven leven. Doch toen het 
hart van dit moedige dier uit het lichaam genomen werd, waren er zeven looden kogels in, de wonden tot groote lidteekenen dichtgegroeid, en hij leefde geruimen tijd met de kogels, want het was lang sinds zij afgeschoten waren. Dit hart bracht de overwinnaar naar ons toe, en het was een groote bezienswaardigheid, die de heele streek bekijken kwam; en die Caesar gelegenheid gaf om een massa mooie verhalen te doen over krijgsvoorvallen, en vreemde ontsnappingen.

Op andere tijden placht hij uit visschen te gaan; en in een gesprek over die uitspanning, hoorde hij, dat wij in dit land een heel vreemde visch, sidder-aal genoemd, hadden (een aal waarvan ik gegeten heb) die, terwijl hij leeft, een zoo kouden aard heeft, dat hij hen die staan te visschen, al hebben zij een snoer van hoe groote lengte ook, met een roede aan het eind daarvan, op hetzelfde oogenblik dat het aas door den aal wordt aangeraakt, hen, zeg ik, die de roede vasthouden, dermate verstijft, dat zij voor een tijd van hun bewustzijn beroofd worden; en sommigen zijn in het water gevallen, en anderen stortten als dood op den oever der rivier waar zij stonden, zoodra deze visch het aas aanraakte. Caesar was gewoon daarover te lachen, en meende dat het onmogelijk was, dat een man zijn kracht verloor door de aanraking van een visch; en kon de gedachte niet begrijpen, dat een koude zelfstandigheid die eigenschap zou bezitten; evenwel, hij was zeer benieuwd te beproeven, of het op hem dezelfde uitwerking had als op iedereen, en stelde vaak pogingen in het werk, maar tevergeefs. Tenslotte kwam de langgezochte visch aan het aas, toen hij op den oever stond te hengelen; en in plaats van de roede weg te werpen, of haar een plotselinge ruk het water uit te geven, waardoor hij zoowel de aal gevangen zou hebben, als de roede kwijtgeraakt voor zij te veel macht over hem zou hebben, pakte hij haar, ter wille van de proef, des te harder en viel bezwijmend in het water ; en daar hij nog altijd den hengel vasthield, voerde de stroom hem, bewusteloos als hij was, een heel eind mede, tot een boot van Indianen hem opnam; en dezen voelden, toen zij hem beetpakten, dat een verstijving hen beving, en daardoor merkten zij dat hij de hengel in zijn hand had; welke zij met een pagaai (dat is een korte riem) daaruit sloegen, en met aal en al in de boot trokken. Als Caesar half dood was door de uitwerking van deze visch, hij was het nog meer door die van het water, 
waar hij den afstand van een mijl gaans in gelegen had, en het bleek hun groote moeite te kosten, om hem weer tot het leven terug te brengen ; maar ten slotte slaagden zij daarin, en brachten hem thuis, waar hij in een paar uur weer geheel hersteld en opgekwikt was, en niet weinig beschaamd over de ondervinding, door een aal overmeesterd te zijn, en bij de gedachte dat iedereen, die zijn uitdagende taal gehoord had, om hem zou lachen. Maar wij vroolijkten hem op; en -toen hij gerustgesteld was, hadden wij aan het avondmaal op tafel de aal, die omstreeks een kwart el lang was, en heel fijn vleesch had; en des te meer waard was, daar hij zooveel als bijna het leven van een zoo edel man gekost had.

Omstreeks dezen tijd waren wij vaak in doodelijke angst naar aanleiding van eenige twisten tusschen de Engelschen en de Indianen; zoodat wij, tenzij in grooten getale, nauwelijks in goed vertrouwen naar de Indiaansche steden of naar een.andere plaats waar zij woonden durfden te gaan, uit vrees, dat zij ons zouden aanvallen, gelijk zij onmiddellijk na mijn vertrek ook deden ; en toen die streek in het bezit der Hollanders was, behandelden dezen hen niet zoo voorkomend als de Engelschen : zoodat zij de huizen binnendringend, alles wat zij krijgen konden stuk sloegen, en de moeder des huizes ophingen en al haar kinderen om haar heen ; en een knecht, die ik achtergelaten had, in stukken sneden, en hem aan de boomen vastspijkerden,

Deze veete begon terwijl ik nog daar was; zoodat ik voor de helft het genoegen verloor dat ik mij voorgesteld had, doordat ik n.1. de Indiaansche steden niet zou zien en bezoeken. Maar op een dag, toen ik over onze tegenslag op dit punt, mijn spijt uitsprak, verteldeCaesar ons, dat wij niet bang behoefden te zijn, want dat, als wij zin hadden om te gaan, hij op zich nam onze geleider te zijn. Sommigen wilden wel, maar de meesten durfden het niet te wagen. Omstreeks achttien onzer besloten er toe, en stapten in de prauwen, en na acht dagen kwamen wij in de buurt van een Indiaansche stad aan. Maar bij de nadering, zonk sommigen van ons gezelschap de moed in de schoenen; en zij durfden niet aan wal te gaan; daarom stemden wij, wie wilden en wie niet. Wat mij betreft zeide ik, als Caesar wil, wil ik ook. Hij besloot er toe; mijn broeder eveneens, en mijn meid, een flinke, moedige vrouw. Daar geen onzer de volkstaal sprak, en wij meenden dat wij, wanneer wij enkel maar zagen, en niet 


\section{6}

wisten wat zij zeiden, maar een half genoegen zouden hebben, namen wij een visscher die zich aan den mond der rivier ophield, en daar reeds langen tijd woonachtig was, en brachten hem er toe met ons mede te gaan. Maar daar hij onder de Indianen bekend was als iemand die handel bij hen dreef, en daar hij, door daar lang te vertoeven, van kleur een volmaakte Indiaan geworden was, werd met het idee om hen te verrassen door hen iets te laten zien, wat zij nog nooit gezien hadden (dat is blanke menschen) besloten dat alleen ik, mijn broeder en mijn meid gaan zouden. Daarom lieten Caesar, de visscher en de rest, zich achter wat dikke rietstengels en bloemen die aan den oever groeiden, verbergend ons voortgaan, naar de stad toe die heelemaal langs den oever van de rivier uitgestrekt lag. Een eindje van de huizen, of hutten, zagen wij er sommigen dansen, anderen bezig met water van de rivier te halen en te dragen. Niet hadden zij ons bemerkt, of zij verhieven een luid geschreeuw, dat ons eerst verschrikte; wij dachten dat het was om mannen te roepen die ons dooden moesten, maar het schijnt dat het van verwondering en verbazing was. $\mathrm{Zij}$ waren allen naakt; en wij waren, zooals het beste is voor de heete landen, schitterend en rijk gekleed; zoodat wij er buitengewoon mooi uitzagen; mijn eigen haar was kort geknipt, en ik had een tafzijden kap, met zwarte veeren op mijn hoofd: mijn broeder droeg een stoffen costuum, met zilveren strikken en knoopen, en een overvloed van groene linten. Het was alles ongeloofelijk verrassend voor hen, en omdat wij hen stil zagen staan tot wij naderden, schepten wij moed en gingen verder, kwamen bij hen en boden ons hunne handen aan; welke zij namen en zij bekeken ons heelemaal in de rondte, telkens meer menschen er bij roepend die in een zwerm naar buiten kwamen, allen vol verwondering, en onder den uitroep van Tepeeme; hun haar in hun handen omhoog houdend, en het breed uitspreidend naar degenen, welke zij naar buiten riepen; alsof zij zeggen wilden (zooals het inderdaad beteekende): „Tallooze wonderen” of "niet” of „niet meer dan de haren van hun hoofd, te tellen”. Langzamerhand werden zij stoutmoediger en na ons eerst van alle kanten aangestaard te hebben, durfden zij ons nu aan te raken, hun handen op al de trekken van ons gezicht leggend, onze borst en armen betastend, een rok optillend en dan vol verbazing er nog een te zien; en schoenen en kousen bewonderend, maar nog 
meer onze kousebanden, die wij hun gaven, en die zij om hun beenen bonden, daar zij aan de einden met zilveren veters doorregen waren; want alles wat glanst boezemt hun achting in. Kortom, wij lieten toe, dat zij ons naar hartelust opnamen, en wij dachten dat er aan hun bewondering voor ons nooit een einde zou komen. Toen Caesar en de anderen bemerkten dat wij met zooveel verbazing ontvangen werden, voegden zij zich bij ons, en toen zij den Indiaanschen koopman, dien zij kenden, bij ons zagen (door deze visschers, immers Indiaansche kooplieden genoemd, onderhouden wij het verkeer met hen, want zij houden er niet van om ver van huis te gaan, en wij gaan nooit naar hen toe) toen zij hem daarom zagen, barsten zij opnieuw in vreugde uit, en riepen in hun taal : „O, daar is onze Tiguamy, en nu zullen wij zien, of deze dingen spreken kunnen”. En aldus op hem toekomende, gaven sommigen hunner hem de hand en riepen: „Amora Tiguamy”, hetgeen zooveel is als: Hoe maakt gij het? of Welkom vriend; en allen in éénen dreun, begonnen zij tegen hem te kakelen, en vroegen of wij verstand en bewustzijn hadden ? Of wij konden spreken over levens- en krijgszaken, zooals zij ? Of wij konden jagen, zwemmen en duizend dingen doen die zij doen konden ? Hij antwoordde hen, dat wij dat konden. Daarop noodigden zij ons in hun huizen, en zetten ons wild en buffelvleesch voor en naar buiten gaande, zochten zij een blad van een boom, dat Sarumbo-blad heet, en zes yards lang is, en spreidden het als een tafellaken op den grond; en een ander in stukjes snijdend om voor borden te dienen, plaatsten zij ons op kleine lage Indiaansche bankjes, die zij uit één stuk hout snijden en eenigszins als Japanwerk beschilderen. Ieder krijgt op zoo'n stuk blad zijn maal opgediend en het smaakte heel goed, maar te sterk gepeperd. Toen wij gegeten hadden, namen mijn broer en ik onze fluiten, en speelden voor hen, hetgeen hun nieuwe verwondering baarde; en ik bemerkte spoedig, door een bewondering die aan de natuur van deze menschen eigen is, en door hun volkomen onwetendheid en eenvoud, dat het niet moeilijk moest zijn, om een onbekende of buitensporige godsdienst onder hen te vestigen, of hun het eene of andere denkbeeld of verdichtsel bij te brengen. Want bij het zien hoe een verwant van mij een stuk papier met een brandglas ontvlammen liet, een kunstje dat zij nooit te voren gezien hadden, waren zij er na aan toe hem als een 
God te aanbidden, en verzochten hem zijn naam of de letters daarvan neer te schrijven, opdat zij die als bezweringsformule tegen winden en stroomen konden gebruiken, hetgeen hij deed, en bij die weersgesteldheden gebruiken $\mathrm{zij}$ hem en verbeelden zich, dat hij tooverkracht had om die te overwinnen, en bewaarden hem als een heilige relikwie. Zij zijn heel bijgeloovig, en noemden hem de Groote Peeie, dat is Profeet. Zij lieten ons hun Indiaansche Peeie zien, een jongen van omstreeks zestien jaar zoo schoon als de natuur een man maar maken kan. Zij wijden daartoe een mooie jongeling van af zijn kindsheid toe, en wenden alle kunst aan, om hem op de beste manier, zoowel in schoonheid als in gestalte, te vervolmaken. Men voedt hem op in al de kleine kunsten en listen, waartoe zij in staat zijn, in al die handige kunstgrepen en behendigheden, waardoor hij indruk maakt op het gemoed, en hij is een geleerde niet alleen in de geneeskunst, maar ook in de religie ; en doet hen door deze kunstjes gelooven, dat hij soms hun pijnen stilt, b.v. door kleine slangen uit het aangetaste lichaamsdeel te trekken, of zonderlinge vliegen, of wormen, of andere vreemde dingen : en hoewel zij behalve dat ongetwijfeld goede geneesmiddelen voor bijna al hun ziekten hebben, genezen zij de patient meer door de verbeelding dan door medicijnen, en maken zichzelf gevreesd, bemind en geëerd. Deze jonge Peeie had een lieve jonge vrouw, die ziende dat mijn broeder haar kuste, op mij kwam toeloopen en mij kuste. Daarna kusten zij elkaar, en maakten er een groota pret van zoo ongewoon was het ; en nieuwe bewondering en gelach verspreidde zich onder de menigte, zoodat zij die "ceremonie” die zij van te voren noch in praktijk brachten, noch kenden, nooit vergeten zullen. Caesar had zin om hun krijgsaanvoerders te zien en zich met hen te onderhouden, en wij werden naar hunne huizen geleid, waar wij verscheidene hunner groote bevelhebbers, die juist krijgsraad gehouden hadden, aanschouwden. Maar een zoo verschrikkelijke aanblik als het was om hen te zien kan geen fantaisie voortbrengen; geen kwade droomen kunnen een zoo vreeselijk schouwspel voorstellen. Wat mij betreft, ik hield hen eerder voor aardgeesten of duivels dan voor menschen. Hoe hun gestalte er echter ook mocht uitzien, hun innerlijk was heel menschelijk en edel; doch sommigen misten hun neus, sommigen hun lippen, sommigen zoowel neus als lippen, sommigen hun ooren, en anderen hadden sneden door iedere wang, met lange splitten, 
waardoor hun tanden te voorschijn kwamen. Zij hadden verscheiden andere ontzaglijke wonden en lidteekenen, of liever verminkingen. $\mathrm{Zij}$ hadden Comitias, of kleine schortjes voor, en katoenen gordels waar hun ontbloote mes in stak, een boog op hun rug, en een pijlkoker aan hun lendenen; en de meesten hadden veeren van verschillende kleuren op hun hoofd. $\mathrm{Zij}$ riepen "Amora Tiguamy” tot ons bij onze binnenkomst en stelden er prijs op dat wij hetzelfde tegen hen zeiden. Zij lieten ons zitten, en gaven ons drank van de beste soort, en verwonderden er zich evenveel over ons te zien als de anderen gedaan hadden. Caesar was even verbaasd over hun gezichten, zich afvragend hoe zij in den krijg allemaal dermate gewond konden zijn; hij was ongeduldig te vernemen, hoe zij allen aan die vreeselijke teekenen, meer van woede en boosaardigheid, dan wonden in edelen krijg opgedaan, gekomen waren. $Z$ ij vertelden ons door onzen tolk, dat wanneer er een oorlog gevoerd werd, twee mannen, uitgekozen door een ouden legeraanvoerder wiens krijgstijd voorbij was, moesten wedijveren om het bevelhebberschap: d.w.z. om groot krijgsoverste te worden; en voor de oude rechters die niet meer strijden kunnen, gebracht, wordt hen gevraagd, wat zij durven te doen om te toonen, dat zij waard zijn een leger aan te voeren. Waarbij hij wien dit het eerst gevraagd wordt, zonder antwoord te geven zijn neus afsnijdt en hem verachtelijk op den grond werpt; en de ander doet zich zelf iets aan, wat dit naar zijn gedachte overtreft, en berooft zich misschien van zijn lippen of van een oog. Zoo kerven zij voort, tot een hunner het opgeeft, en menigeen is in dezen strijd gestorven. En door een passieve onverschrokkenheid dus is het, dat zij hun bekwaamheid tot handelen toonen en bewijzen; een soort van moed, te bruut, om door onzen zwarten held te worden toegejuicht, maar desniettegenstaande sprak hij zijn achting voor hen uit.

POp deze reis bracht Caesar een zoo goede verstandhouding tusschen de Indianen en de Engelschen tot stand, dat er gedurende ons verblijf geen vrees of ontevredenheid meer was; maar wij hadden volmaakt, open en vrij verkeer methen. Vele opmerkelijke en vermeldenswaardige dingen kwamen wij op deze korte reis tegen, doordat Caesar er zijn bezigheid van maakte op zoek te gaan naar en te voorzien in ons onderhoud, in het bijzonder om zijn dierbaar beminde Imoinda te behagen, die een deelge- 


\section{0}

noote was in al onze lotgevallen; daar wij besloten waren, haar de slavernij zoo gemakkelijk mogelijk te maken, en zoo den Prins op de wijze die hem het meeste verplichtte aangenaam te stemmen.

Toen wij daar weder kwamen, ontmoetten wij eenige Indianen van een vreemd aanzien; dat wil zeggen, van een grootere lengte en een ander soort trekken dan die van onze streek. Onze Indiaansche slaven, die ons roeiden, stelden hun een paar vragen; maar zij konden ons niet verstaan, doch lieten ons een lange katoenen strik met verscheiden knoopen zien, en vertelden ons, dat zij van de bergen gekomen waren gedurende zoo vele manen als er knoopen waren. Zij hadden huiden van een vreemd dier aan en brachten buidels met stofgoud mee, hetwelk naar zij ons zoo goed en zoo kwaad het ging verstaan deden, als de regen viel, in kleine smalle geulen van de hooge bergen kwam stroomen; en zij boden aan om iedereen, of allen die naar de bergen gaan wilden, van geleide te dienen. Wij brachten deze mannen naar Parham, waar wij hen hielden tot de heer Gouverneur kwam. En daar het heele land dol was om op goudavontuur uit te gaan, beval de Gouverneur in zijn brieven (want zij zonden iets van het goud aan hem) om een wacht te plaatsen aan den mond van de Amazone-rivier (een rivier, die zoo heette, en die bijna zoo breed als de Theems is) en verhinderde iedereen om de rivier, die hen naar die goudbergen zou voeren, op te gaan. Maar daar wij naar Engeland vertrokken voor het plan verder ten uitvoer gelegd was, en de Gouverneur verdronk bij een orkaan, kwam òf het plan aan zijn eind, of de Hollanders hebben er het voordeel van. En het is te betreuren, wat Zijne Majesteit, door dit deel van Amerika prijs te geven, verloren heeft.

(Slot volgt). 